\title{
EFFECT OF PHYSICAL CONDITIONING ON STUDENT BASIC SKILLS GYMNASTICS
}

\author{
Endang Rini Sukamti*, Ratna Budiarti, Risti Nurfadhila \\ Yogyakarta State University, Indonesia \\ *e-mail: endang_fik@uny.ac.id
}

\begin{abstract}
Physical conditioning was considered as a strong foundation for developing techniques from different fields. The aims of this study was to determine the impact of physical conditioning in parenting students or athletes gymnastic basic skills. The study was a surveyed research. The study sampling was 82 students aged between 18-19 years from Sport sciences, exactly coaching sciences. Data collection methods used checks and measurements of bio motor and gymnastic fundamental skills. Data analysis using correlation and linear regression to predict the future competence. The results showed that: there was significant correlation between the physical conditioning items and gymnastics basics skills, but there is also strong significant linear regression $(p: .032<.05)$ from physical conditioning with basic skill of Gymnastics. The standing balance $(r=.728)$ and broad jump $(r=.751)$ were found more influenced for gymnastic basic skills. There was a great significant different between the pre-test and posttest gymnastic basic skills means with $p$ value $<.001$. The high standard deviation between the items showed the different adaptation of the subjects according to the physical conditioning. In conclusion physical conditioning was found as parenting for developing the gymnastic basic skills.
\end{abstract}

Keywords: gymnastic, physical condition, basic skill

\section{PENGARUH KONDISI FISIK TERHADAP KETERAMPILAN DASAR SENAM SISWA}

\begin{abstract}
Abstrak: Kondisi fisik dianggap sebagai pondasi kuat untuk mengembangkan teknik cabang olahraga. Penelitian ini bertujuan untuk mengetahui pengaruh kondisi fisik dalam pembinaan keterampilan dasar senam atlet. Jenis penelitian adalah studi survey. Sampel penelitian adalah 82 siswa yang berusia antara 18-19 tahun dari Ilmu Keolahragaan, khususnya konsentrasi kepelatian. Metode pengumpulan data dengan menggunakan pemeriksaan dan pengukuran keterampilan dasar motorik senam. Analisis data dengan menggunakan korelasi dan regresi linier untuk memprediksi kompetensi masa depan. Hasil penelitian menunjukkan bahwa: ada korelasi yang signifikan antara item pengkondisian fisik dan keterampilan dasar senam, tetapi ada juga regresi linier yang kuat dengan taraf signifikan $(p: 0,032<$ $0,05)$ dari pengkondisian fisik terhadap keterampilan dasar senam. Keseimbangan berdiri $(r=0,728)$ dan lompatan luas $(r=0,751)$ ditemukan lebih memengaruhi keterampilan dasar senam. Ada perbedaan besar dan signifikan antara keterampilan dasar pre-test dan posttest keterampilan senam dengan nilai $p<0,000$. Simpangan baku yang tertinggi antara item-item menunjukkan adaptasi yang berbeda dari subyek sesuai dengan kondisi fisik. Kesimpulannya pengkondisian fisik ditemukan sebagai Pembina untuk mengembangkan keterampilan dasar senam.
\end{abstract}

\section{Kata Kunci: senam, kondisi fisik, keterampilan dasar}

\section{INTRODUCTION}

In reaching maximum motion abilities in a sport is influenced by means of numerous factors. These elements want to be recognised in order to maximize the fulfilment of the learning process. Gymnastics is one of the sports activities that is taught to sports students (Coppola, Vastola, Scatigna, \& Fabiani, 2015). Gymnastics is a game that consists of quite a few disciplines: creative gymnastics, rhythmic gymnastics, cardio gymnastics, acrobatic gymnastics and tramp lining (White \& Bennie, 2015). In addition to an extremely right vary of youthful gymnasts taking part in gymnastics; the variety of male athletes competing at the amusement and collegiate tiers is reportedly on the rise. Fitnesscomponents have been associated with gymnastics (Sleeper, Kenyon, Elliott, \& Cheng, 2016). Gymnastics is 
an excellent mechanism for the educating basic motor abilities and advertising health-related fitness in youth of all a long time.

Many agree that involvement in gymnastic education can make a contribution considerably to the all-around development of a baby, and that a physical education program along with gymnastics advantages youth in many areas (Bobo-Arce \& Méndez-Rial, 2013). Gymnastics is oftentimes protected in physical education programs throughout the world. It represents an exercise with many benefits, to the point that it has been described as an indispensable and necessary phase of the PE curriculum that have to be provided in preschool through college (Fernández-Villarino, Hernaiz-Sánchez, SierraPalmeiro, \& Bobo-Arce, 2018). One such gain is that it promotes abilities related to health, there are a number of well-known, healthrelated fitness batteries to check health in all its dimensions in younger people (Elferink-Gemser, Huijgen, Coelho-e-Silva, Lemmink, \& Visscher, 2012). Nevertheless, an accelerated ability to precisely measure strength, power, speed, balance, flexibility, and agility can additionally assist in figuring out and re mediating deficits in the bodily basic performance traits desired in gymnastics as some researches consist on the development based on the fitness (Trajković, Madić, Sporiš, Aleksić-Veljković, \& ŽivčićMarković, 2016).

Underlined the significance of bodily health in gymnastics, showing systematically increasing variations over time between gymnasts and non-trained topics in flexibility, speed, strength, agility and endurance tests. Many authors have said that current artistic gymnastics requires greater strength and power due to the fact of the ever increasing technical difficulty required through revision of the Code of Points, previous research has demonstrated the fantastic outcomes of a four-week after faculty programme addressing motor skills and fitness can have in young youth (Donti, Tsolakis, \& Bogdanis, 2014). Positive outcomes from sports activities are completed principally via bodily activity, but secondary effects deliver fitness advantages such as psychosocial and personal development bio motor skills (Eldridge, Palmer, Gillis, Lloyd, Squires, \& Murray, 2012).

There are many gymnastics components: (1) strength is an aspect of a person's bodily situation about the potential to use muscular tissues to take delivery of the burden of work ; (2) endurance the potential of a character to use his muscle mass to contract consistently in a tremendously long time with a sure burden (Mallesh, Suresh, \& Sivakumar, 2017); (3) muscle strength: muscle electricity is the capacity of an individual to use most strength that is performed in the shortest viable time; (4) speed is a person's capacity to work on nonstop moves in the shortest feasible time (Babu \& Kumar, 2013); (5) flexibilityis the effectiveness of a man or woman in adjusting to all activities with huge physique measurements; (6) agility is the ability of anybody to trade the position of a sure area, anybody who is in a position to trade a special function in excessive velocity with correct coordination, ability that the agility is quite appropriate (Gomathi, Radhakrishnan, \& Karthick, 2015); (7) balance is a person's capacity to manage the nerves of the muscular tissues; (8) coordination: coordination is the capacity of a individual to combine a range of extraordinary actions into a single movement pattern effectively (Sammoud, Negra, Chaabene, Bouguezzi, Moran, \& Granacher, 2019); (9) accuracy is the potential of an individual to manipulate free moves towards a target; (10) reaction: reaction is the potential of a character to act without delay as quickly as viable in response to stimuli precipitated via the senses of nerves, or different emotions (Neri et al., 2018; Mellos, Dallas, Kirialanis, Giovanni, \& di Cagno, 2014; Mkaouer, Hammoudi-Nassib, Amara, \& Chaabène, 2018).

Basis of research already carried out by leading researchers. it seems that Indonesia such studies are not yet discussed. Given the importance of gymnastics, the study will be conducted on the influence physical conditioning on the gymnastics basic skills of athletes. The aim of this study to determine the contribution of physical condition to gymnastic basic skill. Good health and fitness allows you to perform daily activities effectively, with good levels of resistance, endurance, flexibility, and cardiorespiratory fitness. Increasing the level of activity reduces the risk of developing pathologies such as hypertension, cardiovascular disease, stroke, diabetes or cancer (Kari \& Karhulahti, 2016).To improve health, it is important to be physically active and follow 
the advice of the American College of Sports Medicine (ACSM), in collaboration with the American Heart Association (Malm, Jakobsson, \& Isaksson, 2019). These recommendations apply to anyone between the ages of 18 and 65 . In general, they recommend at least 30 minutes of physical activity per day.

\section{METHODS}

This study is descriptive research with quantitative approach. The research sampling 82 students, aged between 18-19 years and find out about in Sport Coaching Education Department which belongs to the Sport Science of Yogyakarta, State University. Population was all the students of Sport Coaching Education and the sample was taken by total sampling (Sharma, 2017). Data collection using questionnaire and technique tests (physical condition).To assess the evaluation of gymnastic basic skills the research used the model of Kim, Jang, Kim, \& Wan, (2018). Data analysis using Independent sample t-Test and correlation by SPSS Amos .23.

\section{Procedures}

The instrument used in this study was valid and reliable. The validity of instrument was found out with seven experts: Five lecturers from Yogyakarta State University who have high knowledge in gymnastic, two Gymnastic coaches' trainers who have at least five years of experience, they have also national certificate. Based on Aiken formula the validity and reliability was found (Aiken, 1980; Taherdoost, 2016).
The test of evaluation was constituted by: (1) Physical Ability Test (sit and reach, standing balance, broadjump, vertical jump, side step test agility, push up, and sit up; (2) gymnastic basic skill (forward roll, back roll, tiger sprong, split, Cartwheel, headstand, handstand, roll kip, round off, and handspring.

The training of physical fitness was applied during six weeks three times per week, the evaluation has been carried out to assess the it contribution on the gymnastic basic skills, nevertheless the pre-test has been done before the training in order to know the athlete level at the beginning. The quality of physical training was approved after the last test. The result of program will allow the user to continue with same tool or to improve the methods (Ndayisenga \& Tomoliyus, 2019).

\section{RESULTS AND DISCUSSION Results}

The result from this study consists or focused on the influence from the physical conditioning on the gymnastic basics skills of athletes. The results presented in the tables below are discussed in so far as the researcher begins to show the relationship that would exist between the themes or the variables studied. Then the pre-test and post-test results for physical conditioning and gymnastic basic skills are represented and explained.

Indeed the analysis of the data was firstly based on Correlation between items physical conditioning and gymnastic basic skills. The analytical operations that are performed can be observed in Table 1.

Table 1. Correlation between Items Physical Conditioning and Gymnastic Basic Skills

\begin{tabular}{|c|c|c|c|c|c|c|c|c|c|}
\hline & & $\begin{array}{c}\text { Sit } \\
\text { and } \\
\text { Reach } \\
(\mathrm{X} 1)\end{array}$ & $\begin{array}{l}\text { Standing } \\
\text { Balance } \\
\text { (X2) }\end{array}$ & $\begin{array}{c}\text { Broad } \\
\text { Jump } \\
\text { (X3) }\end{array}$ & $\begin{array}{c}\text { Vertical } \\
\text { Jump } \\
\text { (X4) }\end{array}$ & $\begin{array}{c}\text { Side } \\
\text { Step } \\
\text { Agility } \\
\text { (X5) }\end{array}$ & $\begin{array}{c}\text { Push } \\
\text { Up } \\
\text { (X6) }\end{array}$ & $\begin{array}{l}\text { Sit Up } \\
\text { (X7) }\end{array}$ & $\begin{array}{c}\text { Competence } \\
\text { (Y) }\end{array}$ \\
\hline \multirow[t]{3}{*}{$\begin{array}{l}\text { Sit and Reach } \\
\text { (X1) }\end{array}$} & $\begin{array}{l}\text { Pearson } \\
\text { Correlation }\end{array}$ & 1 & .162 & $.254 *$ & .068 & .147 & $.403 * *$ & .165 & .167 \\
\hline & $\begin{array}{l}\text { Sig. } \\
\text { (2-tailed) }\end{array}$ & . & .197 & .041 & .593 & 242 & .001 & 190 & .184 \\
\hline & $\mathrm{N}$ & 65 & 65 & 65 & 65 & 65 & 65 & 65 & 65 \\
\hline \multirow[t]{3}{*}{$\begin{array}{l}\text { Standing } \\
\text { Balance (X2) }\end{array}$} & $\begin{array}{l}\text { Pearson } \\
\text { Correlation }\end{array}$ & .162 & 1 & .036 & .155 & -.099 & $.269 *$ & -.012 & $.728 * *$ \\
\hline & $\begin{array}{l}\text { Sig. } \\
\text { (2-tailed) }\end{array}$ & .197 & . & .777 & .217 & .433 & .030 & .923 & .000 \\
\hline & $\mathrm{N}$ & 65 & 65 & 65 & 65 & 65 & 65 & 65 & 65 \\
\hline
\end{tabular}




\begin{tabular}{|c|c|c|c|c|c|c|c|c|c|}
\hline & & $\begin{array}{c}\text { Sit } \\
\text { and } \\
\text { Reach } \\
\text { (X1) }\end{array}$ & $\begin{array}{c}\text { Standing } \\
\text { Balance } \\
\text { (X2) }\end{array}$ & $\begin{array}{c}\text { Broad } \\
\text { Jump } \\
\text { (X3) }\end{array}$ & $\begin{array}{c}\text { Vertical } \\
\text { Jump } \\
\text { (X4) }\end{array}$ & $\begin{array}{c}\text { Side } \\
\text { Step } \\
\text { Agility } \\
\text { (X5) }\end{array}$ & $\begin{array}{c}\text { Push } \\
\text { Up } \\
\text { (X6) }\end{array}$ & $\begin{array}{l}\text { Sit Up } \\
(\mathbf{X} 7)\end{array}$ & $\begin{array}{c}\text { Competence } \\
\text { (Y) }\end{array}$ \\
\hline \multirow[t]{3}{*}{$\begin{array}{l}\text { Broad Jump } \\
\text { (X3) }\end{array}$} & $\begin{array}{l}\text { Pearson } \\
\text { Correlation }\end{array}$ & $.254^{*}$ & .036 & 1 & $.751 * *$ & $.666^{* *}$ & .204 & $.386^{* *}$ & $.432 * *$ \\
\hline & $\begin{array}{l}\text { Sig. } \\
\text { (2-tailed) }\end{array}$ & .041 & .777 & . & .000 & .000 & .102 & .001 & .000 \\
\hline & $\mathrm{N}$ & 65 & 65 & 65 & 65 & 65 & 65 & 65 & 65 \\
\hline \multirow[t]{3}{*}{$\begin{array}{l}\text { Vertical Jump } \\
\text { (X4) }\end{array}$} & $\begin{array}{l}\text { Pearson } \\
\text { Correlation }\end{array}$ & .068 & .155 & $.751^{* *}$ & 1 & $.496 * *$ & .094 & $.328 * *$ & $.564 * *$ \\
\hline & $\begin{array}{l}\text { Sig. } \\
\text { (2-tailed) }\end{array}$ & .593 & .217 & .000 & . & .000 & .454 & .008 & .000 \\
\hline & $\mathrm{N}$ & 65 & 65 & 65 & 65 & 65 & 65 & 65 & 65 \\
\hline \multirow{3}{*}{$\begin{array}{l}\text { Side Step } \\
\text { Agility (X5) }\end{array}$} & Pearson & .147 & -.099 & $.666^{* *}$ & $.496^{* *}$ & 1 & .194 & $.389^{* *}$ & $.260^{*}$ \\
\hline & $\begin{array}{l}\text { Sig. } \\
\text { (2-tailed) }\end{array}$ & .242 & .433 & .000 & .000 & . & .122 & .001 & .036 \\
\hline & $\mathrm{N}$ & 65 & 65 & 65 & 65 & 65 & 65 & 65 & 65 \\
\hline \multirow[t]{3}{*}{ Push Up (X6) } & $\begin{array}{l}\text { Pearson } \\
\text { Correlation }\end{array}$ & $.403 * *$ & $.269^{*}$ & .204 & .094 & .194 & 1 & $.480 * *$ & $.510 * *$ \\
\hline & $\begin{array}{l}\text { Sig. } \\
\text { (2-tailed) }\end{array}$ & .001 & .030 & .102 & .454 & .122 & . & .000 & .000 \\
\hline & $\mathrm{N}$ & 65 & 65 & 65 & 65 & 65 & 65 & 65 & 65 \\
\hline \multirow[t]{3}{*}{ Sit Up (X7) } & $\begin{array}{l}\text { Pearson } \\
\text { Correlation }\end{array}$ & .165 & -.012 & $.386^{* *}$ & $.328 * *$ & $.389 * *$ & $.480 * *$ & 1 & $.387^{* *}$ \\
\hline & $\begin{array}{l}\text { Sig. } \\
\text { (2-tailed) }\end{array}$ & .190 & .923 & .001 & .008 & .001 & .000 & . & .001 \\
\hline & $\mathrm{N}$ & 65 & 65 & 65 & 65 & 65 & 65 & 65 & 65 \\
\hline \multirow[t]{3}{*}{$\begin{array}{l}\text { competence } \\
\text { (Y) }\end{array}$} & $\begin{array}{l}\text { Pearson } \\
\text { Correlation }\end{array}$ & .167 & $.728 * *$ & $.432 * *$ & $.564 * *$ & $.260 *$ & $.510^{* *}$ & $.387 * *$ & 1 \\
\hline & $\begin{array}{l}\text { Sig. } \\
\text { (2-tailed) }\end{array}$ & .184 & .000 & .000 & .000 & .036 & .000 & .001 & . \\
\hline & $\mathrm{N}$ & 65 & 65 & 65 & 65 & 65 & 65 & 65 & 65 \\
\hline
\end{tabular}

*. Correlation is significant at the .05 level (2-tailed).

**. Correlation is significant at the .01 level (2-tailed).

The result from the above table showed a strong correlation between the items from physical condition and gymnastic. The result was presented as the following: sit and reach is correlated with broad jump and push up respectively with $p$ value: .041 and .001 . Standing balance was correlated with push up and competence respectively $p$ value: .030 and .000. Broad jump correlated with sit and reach, vertical jump, side step agility, sit up, and competence consecutively $p$ value: .041; $.000 ; .000 ; .001 ; .000$. The vertical jump was correlated with broad jump, side step agility, sit up, and competence with respectively $r=$ $.751 ; .496 ; .328$, and .564 . There was a strong correlation from side step agility and broad jump $(r=.666)$, vertical jump $(r=.496)$, sit up $(r=$ $.389)$, and competence $(r=.260)$. The item push up was correlated with sit and reach, standing balance, sit up and competence respectively with $p$ value: $.001 ; .030 ; .000$, and .000 . Next the sit up item was correlated with broad jump ( $p: .001)$; vertical jump ( $p: .008)$; sit step agility ( $p: .001)$, and competence (p: 0,001). The last correlation was found between competence and standing balance ( $p: .000)$, broad jump ( $p: .000)$, vertical jump ( $p: .000)$, side step agility ( $p: .036)$, push up ( $p: .000)$, and sit up ( $p: .001)$. In few words the data research showed that there is a strong correlation between physical condition and gymnastic basic skills. 
To predict the future value from physical conditioning the research applied linear regression as is it modeling that allows estimates to be made in the future based on information from the past. In this linear regression model, we have several variables, one of which is an explanatory variable and the other of which are explained variables.

Nevertheless a regressive analysis is carried out with the aim of knowing whether physical conditioning would be a tool or a device which will predict the improvement of competence, the result showed in Table 2.

Table 2. Linear Regression Physical conditioning on the Gymnastic Skills

\begin{tabular}{lcc}
\hline Variable & Sig. & Explanation \\
\hline Physical ability gymnastic skill & .032 & significant \\
\hline
\end{tabular}

Linear regression attempts to model the relationship between two variables by fitting a linear equation to observed data. From the result above the linear regression showed that the more physical condition is performed the better is gymnastic. From the table above it can be considered that the results of the linier Regression check confirmed that physical capability have vast impact on gymnastic skill.

This potential that excellent bodily situation will be able to help the appearance of correct gymnastic skills. If a person's bodily condition is no longer correct then his gymnastic look will no longer be maximal. There is need many element to be consist of in artistic. Gymnastics talent scouting instrument. Gymnastics is a type of complicated exercise. There are countless elements or factors wished to do gymnastic movements. Each motion has its personal biomotor structure and needs. So that the influential bio motor will be in accordance with the type of motion carried out. When learning gymnastics competencies one has to stick to methodological standards of complicated motor capabilities acquisition after accomplishing appropriate degree of simple motor capabilities. The anthropometric traits, somatotype, physique composition, and organic maturation traits have been beneficial in the prediction success of the gymnastics opposition. These elements have been used extensively during the initial identification section and the education technique.
Physical conditioning was based on the following elements: (1) Sit and Reach; (2) Standing Balance; (3) Broad Jump; (4) Vertical Jump; (5) Side Step Agility; (6) Push Up; (7) Sit Up. The measurement of the last has been afforded to assess the physical conditioning of subjects before and after. The result is showed in Table 3.

Table 3. Measurement of Physical Conditioning Items

\begin{tabular}{lcc}
\hline Items & Pre-test & Posttest \\
\hline Sit and reach & 37.3615 & 43.1000 \\
Standing balance & 39.0825 & 82.2266 \\
Broad jump & 2.1535 & 2.1646 \\
Vertical jump & 52.86 & 53.46 \\
Side step agility & 20.38 & 39.89 \\
Push up & 34.32 & 37.57 \\
Sit up & 38.17 & 44.74 \\
\hline
\end{tabular}

The above table showed full progress of the items in developing the gymnastic basic skills, there is significant improving between them. After evaluate the physical conditioning items, the following step was to assess the gymnastic basic skills before and after in order to state that there is an influence between physical conditioning and gymnastic competence. The following gymnastic items were assessed: (1) forward rolling; (2) Behind rolling; (3) Tiger Spring; (4) Rolling; (5) Jumping; (6) Split; (7) Handstand1; (8) Handstand2; (9) Roll Kip; (10) Stat; (11) Round Off; (12)Hand Spring. The results from the gymnastic basic skills shown in Table 4.

Table 4. Gymnastic Basic Skills

\begin{tabular}{lcc}
\hline Items & Pre-test & Posttest \\
\hline Behind rolling & 60.77 & 76.20 \\
Tiger spring & 60.40 & 77.12 \\
Rolling & 60.94 & 76.00 \\
Jumping & 64.74 & 76.60 \\
Split & 64.43 & 77.15 \\
Handstand1 & 54.60 & 72.12 \\
Handstand2 & 57.46 & 73.49 \\
Roll kip & 54.22 & 67.26 \\
Stat & 53.38 & 68.89 \\
Round off & 54.15 & 71.66 \\
Hand spring & 53.32 & 66.54 \\
\hline
\end{tabular}


Table 5. Comparison of Pre-Test and Posttest of Gymnastic Basic Skills with 95\% Confidence

\begin{tabular}{|c|c|c|c|c|c|c|c|}
\hline \multirow{2}{*}{$\begin{array}{l}\text { Pre-test \& Posttest Gymnastic } \\
\text { basic Skills }\end{array}$} & \multicolumn{7}{|c|}{ t-test for equality means } \\
\hline & $\boldsymbol{F}$ & Sig & $t$ & $d d$ & $\begin{array}{l}\text { sig(2- } \\
\text { tailled) }\end{array}$ & Means & $S D$ \\
\hline Test equality variance assumed & .509 & .483 & -8.600 & 22 & .000 & 58.4625 & 4.44063 \\
\hline Equality variance no assumed & & & -8.600 & 21.821 & .000 & 73.3933 & 4.05550 \\
\hline
\end{tabular}

The pre-test and posttest result of gymnastic basic skills. The research assessed 12 items (forward rolling, behind rolling, tiger spring, rolling, jumping, split, handstand1, handstand2, roll kip, stat, round off, hand spring) at the beginning, after he applied the physical training during six week and evaluate again the same items. By observation it can be seen that the values are different from pre-test to posttest. The deeply analysis was conducted in the table below (Table 5).

The next step was to assess if there is any difference between the pre-test and posttest value, after the physical conditioning will be qualified as a tool or support of competence or not. To reach the final decision, a comparative analysis was afforded. The result is showed in Table 5 .

The result showed that the gymnastic basic skills like: forward rolling, behind rolling, tiger spring , rolling, jumping, split, handstand1, handstand2, roll kip, stat, round off, and hand spring have been improved if we compare the their pre-test and their post-test, we found a great significant $p$ value ( $p$ : .000). The resume from this research showed that the physical conditioning influenced the gymnastic basic skills.

\section{Discussion}

From the Table 1 it can been seen a strong correlation between physical conditioning and gymnastic basic skills. The positive influence states that physical fitness is a strong tool to improve athlete competence. In the study done by Yadav showed that physical training was used to increase motor health and performance of badminton players (Yadav, 2017). Bodily performance and attack attempts and effectiveness in legit judo suits with special intervals was carried out by physical conditioning (Kons, Franchini, Detanico, \& Franchini, 2018).

Test of linear regression confirmed that physique capability has a big effect on gymnastic skills. This potential that a particular bodily state of affairs will be able to assist creative gymnastics.
Performance in artistic gymnastics is primarily based on a perfect compromise between the stage of physical fitness and the complicated technical capacities required on each device, thus, an immoderate level of ordinary fitness overall performance is decisive for creative men (Agopyan \& Örs, 2019). Physical activity intervention programmes have been found to effectively improve cardiorespiratory fitness, strength, and balance (Sumaryanti, Tomoliyus, \& Ndayisenga, 2019).

On the Table 3 the means of physical conditioning on pre-test and posttest are different which stated that the value found at the beginning has a low level, the more the subject practice the more they improve their physical fitness like strengthen coordination, agility, speed and etc. Mkaouer et al. (2018) found that gymnastics for girls is a multifaceted pastime that requires a high level of physical health. And capabilities to succeed. Speed, strength, 2 endurance, agility, 7 flexibility, stability and electricity are all physical abilities that play a role in the success of an aggressive gymnast.

In addition, the physical capabilities of a gymnast can be related with the capability to maintain protected participation in sport. Gymnastic jumping is one of the many approaches you can wear when you get closer to a goal. Long jumps and pole vault have a much less complicated impact after the flight, but are similar to the gymnastics soar in the strategic movement.

Taufiqurriza (2012) stated that one of the functions of gymnastic formation is to make the physique remain in a state of proper attitude, and if an incorrect posture occurs, it must without delay right it, so that it will become correct. Furthermore, a few possibilities that can motive the prevalence of wrong posture include: Innate from birth, Less or not fulfilled food, substances, disease or accident, weakness of the muscle groups of the body, weakness of skeletal bones, wrong habits (Rofika \& Yuniastuti, 2018). Mistakes in posture brought about by using 
the possibility these possibilities include: (1) kyphosis, which is a structure of bodily error brought about by protrusion curvature of the backbone of the back. If the returned of the spine bends, then the the front of the spinal association becomes concave. (2) lordosis, which is a form of physique error caused via protrusion of the spine in the lumbar region, lumbar region, so that the again of the spinal column is curved, and the pelvis is typically pushed forward down. This situation reasons the returned of the waist muscle groups appear short (So'emah, Haryanto, \& Akbar, 2017). Scoliosis, which is a form of physique error caused by spinal deviations (Abdollahipour, Wulf, Psotta, \& Nieto, 2015).

If the deviation is viewed from the back, the protrusions of the spine are not in a straight line, deviations can take place to the left or right, toward the again or in the direction of the waist (Rogers, Page, \& Takeshima, 2013). Preventive efforts that can be carried out so that adolescents keep away from errors in attitudes and basic movements of the physique is to get youth to constantly make the right attitude and movement. We want to be aware of the habits of subjects, especially in the school surroundings that can have an adverse effect on posture, such as the addiction of sitting incorrectly at some stage in category lessons, or the habit of carrying a school bag, which can allow youth to have kyphosis and ordosis, posture Rejeki, Rahim, \& Prasetya (2018) said that the right posture with self-habituation as long as teenagers are nevertheless in the stage of boom has enormous have an impact on and benefits for their lives in the future, such as: (1) helping the growth of adolescents in the path they need to prevent structure blunders and posture two; (2) prevent habits that should not; (3) living up to the importance of getting to know posture and gestures.

The result from the study showed that there was an important improvement from physical conditioning to the gymnastic basic skills. For typically physical sports such as running or cross-country cycling, the very nature of the sport requires significant physical preparation. But it is also essential in all other sports (Azmi \& Kusnanik, 2018). General physical preparation is the organized and hierarchical set of sports training procedures, training aimed at the development and use of the physical qualities of the sportsman (Yustika, 2018). Indeed, exercise can help you: improve your muscle tone; release the stress; improve your body image; increase your energy and concentration levels; protect your bones; stimulate your circulation; improve your digestive health.

Physical conditioning allows athlete to have a good physical fitness (flexibility, strengthening of muscles, etc. ...). It therefore improves endurance (ability to resist fatigue), strength, coordination (skill, precision) and fitness (Kuswanto, 2012).

\section{CONCLUSION}

The problems that were raised at the outset of seeking whether there would be a correspondence between physical conditioning and gymnastic basics skill were answered first by showing the correlation that exists between the variables. Some gymnastic elements evaluated were: the front roll, rear roll, wheel, tige.etc. Gymnastics formation or referred fundamental gymnastics is a body workout that used to be chosen and created intentionally, planned, arranged systematically and methodically, with the intention to form the body. The subject's physique desires to be formed primary mind-set and action first, so that the body is always in the proper country of attitude. Understanding the mind-set of the attitude of the body in a nation of silence and in a country of movement. Silent posture, such as standing, squatting, sitting, and lying down, while posturing, such as walking, running, jumping, jumping, hitting, and kicking. Each movement has different biomotor needs. The trainer must train the dominant biomotor used."Talent detection and talent development: kinanthropometric.

This study was based on the evaluation of the physical conditioning about the gymnastic basic skills, the result showed that there were positive impacts for developing the performance of the students or athletes. For physical teachers and coaches they invited to use the last latest for increasing the outcomes escorted. Physical conditions have an important role in achieving good gymnastic performance. Research confirms that healthy young people make better competence. The training of physical conditioning" is used to perform: skill level, culture and unique needs of the student (Taufiqurriza, 2012). Physical 
conditioning allows students to better know their bodies and participates in safety education by encouraging risk-taking under control. It allows the transmission of ethical and social values, promotes self-confidence and the development of self-esteem, educates in autonomy and responsibility, gives meaning to associative life and "living together" and allows students to find a place in a group, to be accepted by others, to self-assess, to measure themselves against each other and to adapt easily to their environment. Physical conditioning also has positive effects on the subject's competence.

\section{ACKNOWLEDGMENT}

The researcher thankful to the participants on this study especially students and physical training of Yogyakarta State who accepted with voluntary to participate in the research.

\section{REFERENCES}

Abdollahipour, R., Wulf, G., Psotta, R., \& Nieto, M. P. (2015). Performance of gymnastics skill benefits from an external focus of attention. Journal of Sports Sciences, 33(17), 1807-1813. doi:10.1080/0264041 4.2015.1012102.

Agopyan, A., \& Örs, B. S. (2019). An analysis of variations in body movement difficulty of 2016 Olympic Games rhythmic gymnast candidates. International Journal of Performance Analysis in Sport, 19(3), 417-434. doi:10.1080/24748668.2019.16 17017.

Aiken, L. R. (1980). Content validity and reliability of single items or questionnaires. Educational and Psychological Measurement, 40(4), 955959. doi:10.1177/001316448004000419.

Azmi, K., \& Kusnanik, N. W. (2018). Effect of exercise program Speed, Agility, and Quickness (SAQ) in improving speed, agility, and acceleration. Journal of Physics: Conference Series, 947(1), 1-5. doi:10.1088/1742-6596/947/1/012043.
Babu, M. S., \& Kumar, P. P. S. P. (2013). The effect of selected circuit training exercises on sprinters of high school girls. International Journal of Science and Research (IJSR), 2(11), 401-407. http:// www.ijsr.net/.

Bobo-Arce, M., \& Méndez-Rial, B. (2013). Determinants of competitive performance in rhythmic gymnastics: A review. Journal of Human Sport and Exercise, $8(3$ PROC), 711-727. doi:10.4100/ jhse.2013.8.Proc3.18.

Coppola, S., Vastola, R., Scatigna, M., \& Fabiani, L. (2015). Training and health in gymnastics. Journal of Human Sport and Exercise, 10(Proc1), 391-398. doi:10.14198/jhse.2015.10.proc1.30.

Donti, O., Tsolakis, C., \& Bogdanis, G. C. (2014). Effects of baseline levels of flexibility and vertical jump ability on performance following different volumes of static stretching and potentiating exercises in elite gymnasts. Journal of Sports Science and Medicine, 13(1), 105-113. http:// www.jssm.org.

Eldridge, J. A., Palmer, T. Y. B., Gillis, K., Lloyd, R., Squires, W. G., \& Murray, T. D. (2012). Comparison of academic and behavioral performance between athletes and non-athletes International Journal of Exercise Science, 7(1), 3-13. doi:10.1016/j.jsams.2012.11.418.

Elferink-Gemser, M. T., Huijgen, B. C., Coelhoe-Silva, M., Lemmink, K. A. P. M., \& Visscher, C. (2012). The changing characteristics of talented soccer players: A decade of work in Groningen. Journal of Sports Sciences, 30(15), 1581-1591. do i: $10.1080 / 02640414.2012 .725854$.

Fernández-Villarino, M. A., Hernaiz-Sánchez, A., Sierra-Palmeiro, E., \& Bobo-Arce, M. (2018). Performance indicators in individual rhythmic gymnastics: Correlations in competition. Journal of 
Human Sport and Exercise, 13(3), 487493. doi:10.14198/jhse.2018.133.01.

Gomathi, N., Radhakrishnan, R., \& Karthick, M. (2015). Effect of circuit training on selected skill related fitness parameters among engineering professional sportsmen. Physical Eduction, 4(10), 1-5. doi:10.9780/ 22773665.

Kari, T., \& Karhulahti, V. M. (2016). Do e-athletes move? A study on training and physical exercise in elite e-sports. International Journal of Gaming and Computer-Mediated Simulations, 8(4), 5366. doi:10.4018/IJGCMS.2016100104.

Kim, H., Jang, S. M., Kim, S., \& Wan, A. (2018). Evaluating sampling methods for content analysis of twitter data. Social Media + Society, 1-10. doi:10.1177/2056305118772836.

Kons, R. L., Franchini, E., Detanico, D., \& Franchini, E. (2018). Relationship between physical fitness, attacks and effectiveness in short- and long-duration judo matches. International Journal of Performance Analysis in Sport, 00(00), 1-13. doi:10.10 80/24748668.2018.1545198.

Kuswanto, C. W. (2012). Pengaruh latihan sprint di pasir dan sprint di tempat keras terhadap kecepatan tendangan sabit kategori tanding (Studi eksperimen di Universitas Ahmad Dahlan). Jurnal Olahraga Prestasi, 12(1), 63-77. doi:10.21831/jorpres.v12i1.9497.

Mallesh, A., Suresh, T. N., \& Sivakumar, V. P. R. (2017). Effectiveness of sports specific circuit training and high intensity interval training on aerobic capacity in male basketball players. International Journal of Clinical Skills, 11(6), 1388-1393. doi:10.4172/clinical-skills.1000130.

Malm, C., Jakobsson, J., \& Isaksson, A. (2019). Physical Activity and Sports-Real Health Benefits: A Review with Insight into the Public Health of Sweden. Sports, 7(127), 1-28. doi:10.3390/sports7050127.
Mellos, V., Dallas, G., Kirialanis, P., Giovanni, F., \& di Cagno, A. (2014). Comparison between physical conditioning status and improvement in artistic gymnasts and non-athletes peers. Science of Gymnastics Journal, 6(1), 33-43.

Mkaouer, A. B., Hammoudi-nassib, S., Amara, S., \& Chaabène, H. (2018). Evaluating the physical and basic gymnastics skills assessment for talent identification in men's artistic gymnastics proposed by the International Gymnastics Federation. Biology of Sport, 35(4), 383-392. doi:10.5114/biolsport.2018.78059.

Ndayisenga, J., \& Tomoliyus, T. (2019). Effect of service quality and rates on satisfaction and loyalty of customer behavior at fitness. International Journal of Human Movement and Sports Sciences, 7(2), 2532. doi:10.13189/saj.2019.070202.

Neri, T., Dalcol, P., Palpacuer, F., Bergandi, F., Prades, J. M., Farizon, F., ... Peoc'h, M. (2018). The anterolateral ligament is a distinct ligamentous structure: A histological explanation. Knee, 25(3), 360-366. doi:10.1016/j.knee.2018.03.012.

Rejeki, P. S., Rahim, A. F., \& Prasetya, R. E. (2018). Effect of physical training towards body balance in overweight condition. Biomolecular and Health Science Journal, 1(2), 141-144. doi:10.20473/ bhsj.v1i2.9966.

Rofika, A., \& Yuniastuti, A. (2018). Effectiveness of tera gymnastics and healthy heart gymnastics on blood pressure among elderly with hipertension in Sinomwidodo Village, Tambakromo Subdistrict, Pati District. Public Health Perspective Journal, 3(1), 7-12. https://journal. unnes.ac.id/nju/index.php/phpj/article/ view/13455.

Rogers, M. E., Page, P., \& Takeshima, N. (2013). Balance training for the older athlete. International Journal of Sports Physical Therapy, 8(4), 517-530. http://www.ncbi. nlm.nih.gov/pubmed/24175135. 
Sammoud, S., Negra, Y., Chaabene, H., Bouguezzi, R., Moran, J., \& Granacher, U. (2019). The effects of plyometric jump training on jumping and swimming performances in prepubertal male swimmers. Journal of Sports Science and Medicine, 18(4), 805-811. https://www. jssm.org/mob/ajssm-18-805.xml.

Sharma, G. (2017). Pros and cons of different sampling techniques. International Journal of Applied Research, 3(7), 749-752.

Sleeper, M. D., Kenyon, L. K., Elliott, J. M., \& Cheng, M. S. (2016). Measuring sportspecific physical abilities in male gymnasts: The men's gymnastics functional measurement tool. International Journal of Sports Physical Therapy, 11(7), 10821100. https://www.ncbi.nlm.nih.gov/pme/ articles/PMC5159633/.

So'emah, E. N., Haryanto, A., \& Akbar, A. (2017). Effect of ergonomic gymnastic to lipid profile and blood pressure in patien with hypertension at Sumber Agung Village Jatirejo District Mojokerto Regency. International Journal of Nursing and Midwifery Science, 1(1), 14-25. doi:10.29082/IJNMS/2017/Vol1.Iss1.24.

Sumaryanti, S., Tomoliyus, T., \& Ndayisenga, J. (2019). Circuit training intervention for adaptive physical activity to improve cardiorespiratory fitness, leg muscle strength static and balance of intellectually disabled children. Sport Mont, 17(3), 97100. doi:10.26773/smj.191019.
Taherdoost, H. (2016). Validity and reliability of the research instrument: How to test the validation of a questionnaire/survey in a research. International Journal of Academic Research in Management (IJARM), 5(3), 28-36. doi:10.2139/ ssrn.3205040.

Taufiqurriza, H. (2012). Tingkat keterampilan dasar permainan sepak bola pada siswa sekolah dasar. Journal of Physical Education, Sport, Health and Recreations, 1(1), 1957-1962. doi:10.15294/active. v1i1.266.

Trajković, N., Madić, D., Sporiš, G., AleksićVeljković, A., \& Živčić-Marković, K. (2016). Impact of gymnastics program on health-related fitness in adolescent pupils. Science of Gymnastics Journal, 8(2), 157166.

White, R. L., \& Bennie, A. (2015). Resilience in youth sport: A qualitative investigation of gymnastics coach and athlete perceptions. International Journal of Sports Science and Coaching, 10(2-3), 379-393. doi:10.1260/1747-9541.10.2-3.379.

Yadav, S. Kr. S. (2017). Relationship of selected motor fitness variables with the performance of badminton players. International Journal of Physical Education, Sports and Health, 4(2), 145147.

Yustika, G. P. (2018). Fisiologi dalam permainan sepakbola profesional: Studi literatur. [Physiology in professional soccer games: Study of literature]. Jurnal Pendidikan Jasmani Olahraga, 7(1), 22-39. doi:1037//0033-2909.I26.1.78. 